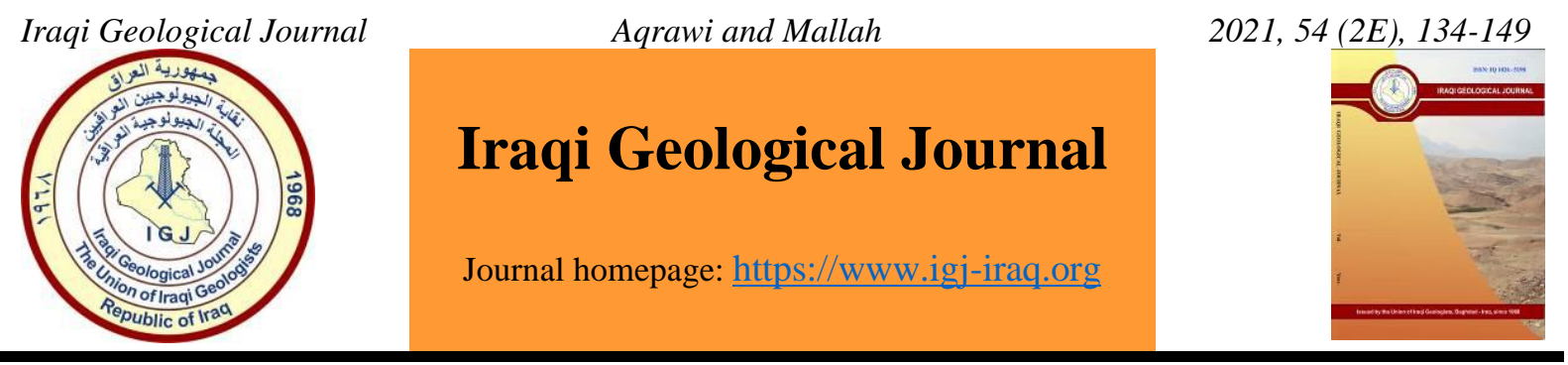

\title{
Hydrogeochemical Assessment of Selected Springs Water in Aqra Area, Duhok Governorate, Northern Iraq
}

\author{
Omar S. Aqrawi ${ }^{1, *}$ and Aahed Y. Al-Mallah ${ }^{1}$ \\ 1 Department of Geology, College of Science, University of Mosul, Mosul, Iraq \\ * Correspondence: omar.akreyi86@gmail.com
}

Received: 3 July 2021; Accepted:13 August 2021; Published: 30 November 2021

\begin{abstract}
Fifteen spring water samples were collected from the study area, to identify its quality, as well as the prevailing water type in it. samples were analyzed to determine the concentrations of main cations $\mathrm{Ca}^{2+}, \mathrm{Mg}^{2+}, \mathrm{Na}^{+}$, and $\mathrm{K}^{+}$, and anions $\mathrm{HCO}_{3}^{-}, \mathrm{SO}_{4}{ }^{2-}, \mathrm{Cl}^{-}$and $\mathrm{NO}_{3}^{-}$, as well as investigating the physio-chemical properties represented by Hydrogen Number, Electrical Conductivity, and Total Dissolved Solids. Piper classification demonstrated that all samples are of type normal earth alkaline water with prevailing bicarbonate with a percentage of $79.9 \%$ of all the samples, except for SP4, SP9, and SP11, which characterized with normal alkaline water with prevailing bicarbonate and sulfate or chloride with a percentage of $19.9 \%$. The results of the analysis showed a prevalence of calcium ions over the rest of the cations followed by $\mathrm{Mg}^{2+}, \mathrm{Na}^{+}$, and $\mathrm{K}^{+}$, and a prevalence of $\mathrm{HCO}_{3}{ }^{-}$ion over the rest of the anions followed by $\mathrm{NO}^{3-}, \mathrm{Cl}^{-}$, and $\mathrm{SO}_{4}{ }^{2-}$. The water quality index showed that all samples are categorized within the excellent type for drinking, with a range of 13.14-29.94. In addition, several classifications used (Eaton, 1950, Turgeon, 2000 and Don, 1995) demonstrated that the water is of excellent type to use for irrigation with $\mathrm{Na} \%=2.51$, Sodium Adsorption Ratio $=0.08$, and $\mathrm{RSC}=-1.65$. Using Wilcox Diagram for irrigation water; show that all samples are within the domain of the excellent water for irrigation.
\end{abstract}

Keywords: Aqra; Spring water; Hydrogeochemistry; Irrigation

\section{Introduction}

Springs are one of the important sources that provide humans with water for drinking, domestic, and other daily uses. Because water is necessary for all uses, therefore it is important to monitor the sources of water regularly to determine whether this water is healthy or not (Awadh et al., 2021). Moreover, springs are a major source of drinking water, agriculture, and industries in many cities around the world as the water of these springs is of high quality, and on many occasions, it doesn't need filtering or purification before consumption (Awadh and Al-Ghani, 2014; Al-Hamdani et al., 2016). Springs can be defined as those spots of land from which water spurts naturally or forming ponds (Boschetti et al., 2018; Medler\& Eldridge, 2021). Also, there is another term, which is seep that stands for a sort of springs that emerge due to the slow movement of water through the slits, pores, and rock perforations and flow out from the surface (U.S. Geological Survey, 2019) and this type of springs is the one that exists in the study area. (Meuli \& Wehrle, 2001) explained that the quantity and quality of the spring waters depend on several factors including the annual rainfall, type of rock the water passes through, 
the nature and slope of the surface and the quality of waters that feed these springs. Water quality is influenced by the chemical reaction between the water and its geological environment as infiltration through soils and the reactions of the groundwater and the surface water with the water-retaining rocks (Awadh and Ahmed, 2013). Usually, the agricultural and domestic wastes find their way into the groundwater system leading to the change of the chemical components of the groundwater and thus the spring water (Dikeogu et al., 2018).

The water used for human consumption must be free of chemical and organic pollutants that may be harmful to human health and that the concentrations of chemical elements fall within the global standards recommended by the World Health Organization (WHO), and it shall be free from turbidity, color, or any unacceptable taste or smell (Hem, 1985). The quality of water is greatly affected by natural resources as physical and chemical processes such as rock weathering, climate, and the amount of rainfall, in addition to human resources (Hadgu et al., 2014). The area of Aqra has a large number of springs; most of them are located at the two anticlines (Aqra and Peris). A large number of the village's populations and even some of the neighborhood's inhabitants inside Aqra city depend basically on the spring waters for drinking and irrigation. The population expansion in Aqra increased greatly in recent years along with the expansion in the economic and agricultural activities, livestock projects, tourist, and environmental development projects, this posed an increasing demand for water to meet the requirements of these purposes (Awadh, 2018). The springs spreading along the extremes of Aqra and Peris anticline depend on rainwater and snows; especially, they exist on a higher level than the groundwater in the area. The study area is characterized by a variety of geological formations and a great complexity, so this variation in the geological structure definitely influences the properties of the water as many of these springs are flows at the contact area amongst the different formations, which result in differences in the chemical properties of the water from which it streams.

Due to lack of detailed studies, previous or recent for the water of Aqra city (particularly the area between Aqra anticline and Peris anticline) which depends $100 \%$ on springs water in daily use, therefore; this study was conducted to investigate the specific properties of the springs water in this area as no other studies were conducted, The most recent study was limited to studying Aqra basin that extends from south of Aqra to Rovia sub-district through a study conducted by Ahmed \& Almohseen (2019); also this study employed the geochemical explanation of the groundwater relying on previous data concluded by Aqrawi (1990) that involved a hydrological study of Aqra plain, which extends to the south of Aqra to Maqloob Mountain. The current study aims to evaluate the chemical properties of spring's water in Aqra city and its suburbs to identify if the water is suitable for drinking, irrigation, and other daily uses because the physical and chemical properties of this water are so important to determine its suitability for domestic uses or irrigation purposes (Hamill and Bell, 1986).

\section{The study area}

The Aqra area is located in northern Iraq and the eastern part of Duhok, about 85 kilometers northeast of Mosul City. The study area lies between latitudes $36^{\circ} 31^{\prime} 56^{\prime \prime}$ and $37^{\circ} 02^{\prime} 15^{\prime \prime}$ North, and longitudes $43^{\circ} 54^{\prime} 15^{\prime \prime}$ and $44^{\circ} 18^{\prime} 65^{\prime \prime}$ East which cover an area of about $1835 \mathrm{Km}^{2}$ (Fig. 1). The area bordered on the North and East by the Greater Zab river and from the west Al-Khazir river in addition to a set of branch rivers and creeks.

Aqra climate is the same as the climate of Iraq, it's characterized by a continental climate semi-arid according to the taxonomy and distribution of the climatic regions prepared by Koppen-Geiger which pivots basically on the size of rainfall and the monthly and annual temperatures. So, the area is featured by $763.07 \mathrm{~mm}$ as an average rainfall for the period 2001-2020, and $12.17 \mathrm{~cm}$ as an average of snowfall, the average annual temperature is $20.75 \mathrm{C}^{\circ}$, the highest value of evaporation was $22.4 \mathrm{~mm}$ in July, and the average relative humidity was $63.3 \%$ in January for the same period. 


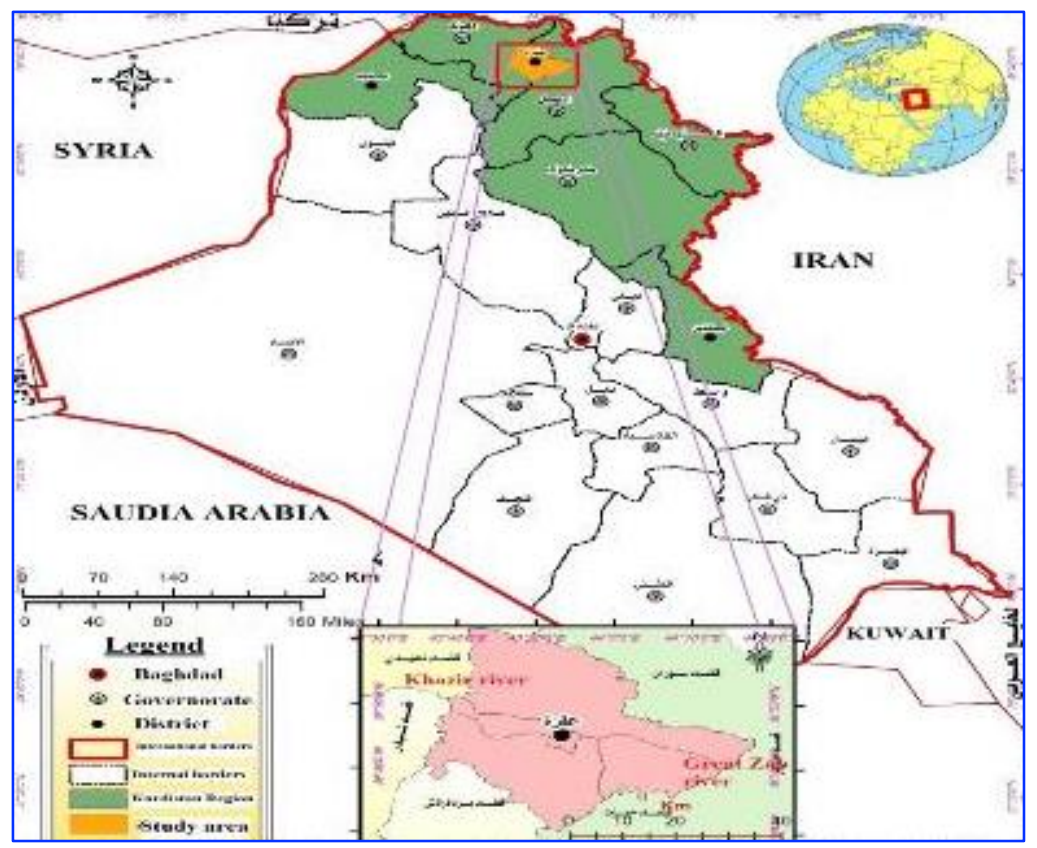

Fig.1. Location map of the study area

\section{Stratigraphy of the study area}

The study area is characterized by a variety of geological facies, which are mostly distributed along Aqra and Peris anticlines. Also, it is featured with rough and complicated topography. The Bai Hassan Formation and the sediments of the quaternary spread in the south of the study area and cover a considerable part of it, these sediments are spread to form hills and valleys in the southern and southeast parts of the area, followed by the formations of Al-Mukdadiya, Injana, Fatha, Pila spi, Kolosh, AqraBakhme, and Qamchuqa in the peaks of the mountains. Peris anticline is located to the north of Aqra anticline, and these two anticlines are extending in a parallel manner together, as shown in Fig. 2. The two anticlines consist of various formations, but the limestone and dolomitic limestone prevail, which form Pila spi, Aqra-Bakhme, and Qamchuqa formations. Also, these formations include a great number of cracks, faults, and pores that allow the infiltration of rainwater and snow, and then this water pours out of the surface as springs. At the area between the two anticlines, formations of Fatha, Mukdadiya, Injana, and the sediments of the quaternary are exposed. Aqra and Bakhme formations are consist of reef limestone, Aqra Fm. is locally dolomitized, siliceous, and impregnated with bitumen, Bakhme is secondary dolomitized, the Pila Spi Formation comprises well-bedded, bituminous, chalky, and crystalline limestone, with bands of white, chalky marl, and with chert nodules towards the top (Jassim \& Goff, 2006), the formation spreads on both sides of the Aqra fold as a belt with a thickness of $85 \mathrm{~m}$ and a widespread, especially in the northwest of the fold depression (Ghafur et al., 2019). The Fatha Formation components are various, it comprises anhydrite, gypsum, and salt inter bedded with limestone and marl, the formation appears in the Aqra fold, as it follows the formation of Pila Spi in an unconformity manner (Aqrawi, 1990). The Injana Formation comprises thin-bedded calcareous sandstone and red and green mudstones (Jassim \& Goff, 2006), the Muqdadiya Formation consists of a sequence of gravel, sand, alluvium, and reddish clay stone of different sizes, the Bai Hassan Formation is mainly formed of Massive Conglomerate and involve coarse river components and Conglomerates that represent the river mouths.To the far northern boundary of Aqra (beyond Peris anticline), the complicated topography continues until the Greater Zab River, which separates Aqra from Merga Sur district from the north. 


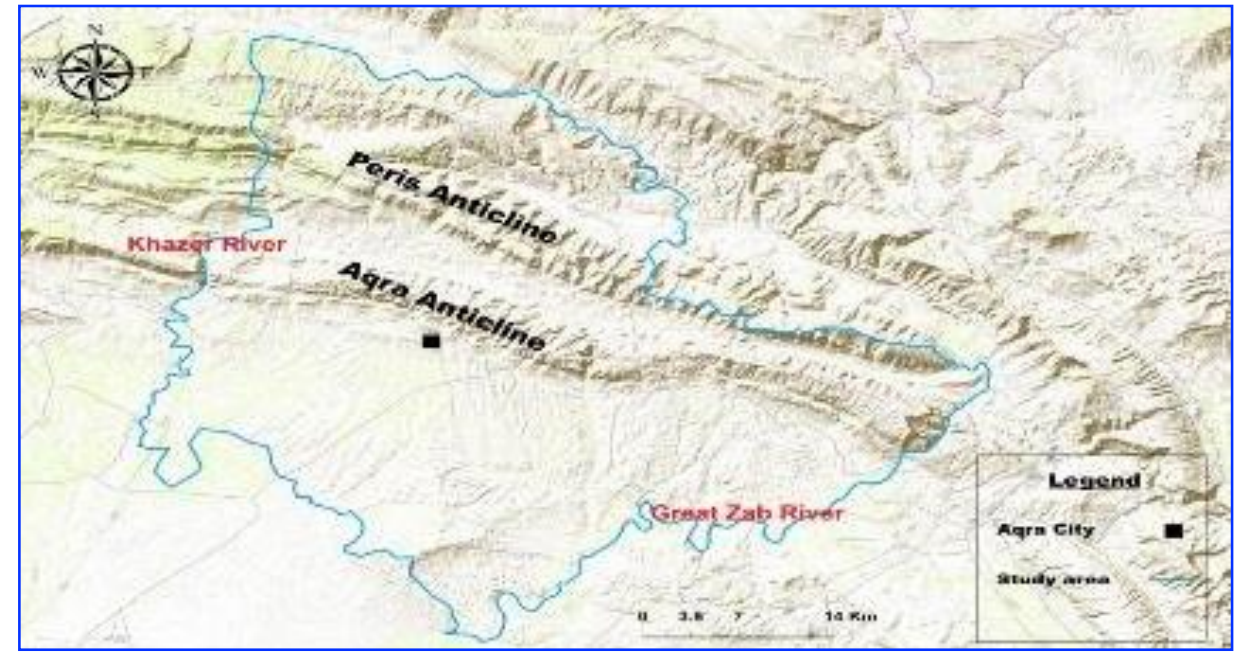

Fig.2. The extension of Aqra and Peris anticlines in the area of study

\section{Materials and Methods}

Fifteen springs were selected to collect water samples, from the middle of July, until the end of August 2020. Samples locations were dropped by a portable GPS device, the sites from which the samples take; were selected by using ArcMap GIS software after defining the boundaries of the study area. After that, 15 springs were chosen, which are distributed between the center of Aqra city and to the east, and west at the Aqra foothill zone from the northern and the southern limbs, also, some of these springs are distributed at Peris foothill zone, the springs are distributed to various elevations which reach to a height of 910 m.a.s.l. (Fig. 3 and Table 1).

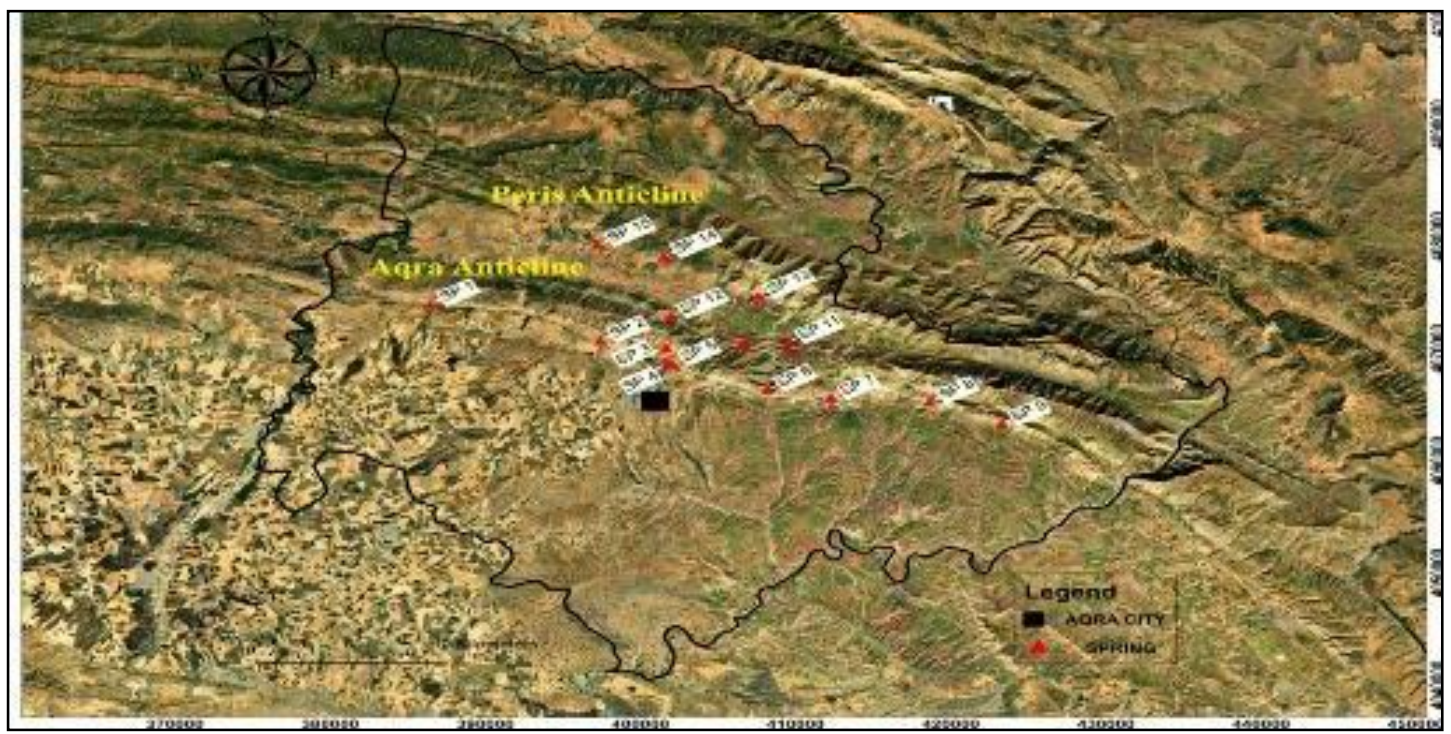

Fig.3. Google Earth map shows the locations of springs in the study area

Table 1. Shows the coordinates of the springs, their elevation, and the geological formation

\begin{tabular}{ccccc}
\hline Spring & Longitude & Latitude & Elevation (MSL) & Geological Fm. \\
\hline SP 1 & $36^{\circ} 48^{\prime} 18^{\prime \prime}$ & $43^{\circ} 43^{\prime} 38^{\prime \prime}$ & 779 & Aqra \\
\hline
\end{tabular}




$\begin{array}{cl}\text { SP 2 } & 36^{\circ} 46^{\prime} 36^{\prime \prime} \\ \text { SP 3 } & 36^{\circ} 46^{\prime} 17^{\prime \prime} \\ \text { SP 4 } & 36^{\circ} 45^{\prime} 37^{\prime \prime} \\ \text { SP 5 } & 36^{\circ} 45^{\prime} 31^{\prime \prime} \\ \text { SP 6 } & 36^{\circ} 44^{\prime} 19^{\prime \prime} \\ \text { SP 7 } & 36^{\circ} 43^{\prime} 56^{\prime \prime} \\ \text { SP 8 } & 36^{\circ} 43^{\prime} 46^{\prime \prime} \\ \text { SP 9 } & 36^{\circ} 42^{\prime} 45^{\prime \prime} \\ \text { SP 10 } & 36^{\circ} 46^{\prime} 31^{\prime \prime} \\ \text { SP 11 } & 36^{\circ} 46^{\prime} 38^{\prime \prime} \\ \text { SP 12 } & 36^{\circ} 47^{\prime} 48^{\prime \prime} \\ \text { SP 13 } & 36^{\circ} 48^{\prime} 49^{\prime \prime} \\ \text { SP 14 } & 36^{\circ} 50^{\prime} 42^{\prime \prime} \\ \text { SP 15 } & 36^{\circ} 51^{\prime} 14^{\prime \prime}\end{array}$

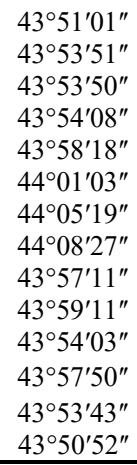
the same water of the samples, and they were filled to the top then these bottles were put in a refrigerator that contains ice to preserve them until they are taken to the laboratory. Analyses were conducted in the laboratories of Duhok Environment Directorate to determine the concentrations of the main cations $\mathrm{Ca}^{2+}, \mathrm{Mg}^{2+}, \mathrm{Na}^{+}$and $\mathrm{K}^{+}$; and the anions $\mathrm{HCO}_{3}{ }^{-}, \mathrm{Cl}^{-}, \mathrm{SO}_{4}{ }^{2-}$, and $\mathrm{NO}_{3}{ }^{-}$. $\mathrm{As}^{2+}$ and $\mathrm{Mg}^{2+}$ ions were estimated using EDTA Titrimetric Method; and the ions $\mathrm{Na}^{+}$and $\mathrm{Ca}^{2+}$ were measured using PFP7 Flame photometer. Moreover, to measure $\mathrm{HCO}_{3}{ }^{-}$ions, titration with the sulfuric acid method was used and by using the methyl orange as an index. For the estimation of $\mathrm{SO}_{4}{ }^{2-}$ ions Turbidimetric Method was used by Nephelometer and the Spectrophotometer $420 \mathrm{~nm}$ after adding a buffer and $\mathrm{BaCl}_{2}$. The concentration of $\mathrm{Cl}^{-}$was estimated by titration with $\mathrm{AgNO}_{3}$ standard solution and by using $\mathrm{K}_{2} \mathrm{CrO}_{3}$ solution as an index. to measure $\mathrm{NO}_{3}{ }^{1-}$ a UV Spectrophotometer was used and by adding $\mathrm{HCl}$. Moreover, the hydrochemical parameters Hydrogen number $(\mathrm{pH})$, Electrical Conductivity (EC), Total Dissolved Solids (TDS), and Total Hardness (TH) were determined in the spring waters. To measure and verify the accuracy of the analyses, the ionic balance measure was used the equivalent per million (epm) values for the main cations and anions by using the following formula (Baird, 2017):

$$
\mathrm{E} \%=(\text { r. cat. } \Sigma \text { r. ani }) /(\text { r. cat. }+\Sigma \text { r. ani. }) * 100
$$

Where:

$\mathrm{E} \%=$ the percentage of the error

$\Sigma$ r.cat $=$ summation of positive ions concentrations $($ epm $)$

$\Sigma$ r.ani $=$ summation of negative ions concentrations $($ epm $)$

As for the accuracy, the following formula was used:

$$
A=100-E \%
$$

Where:

$\mathrm{A}=$ the percentage of analysis accuracy $(\%)$.

$\mathrm{E} \%=$ the percentage of the error.

The accuracy of the analyses is very high if the error percentage is less than $5 \%$, but if the error percentage is between $5 \%-10 \%$, then cautions should be taken in terms of the interpretations. Moreover, if the value was bigger than $10 \%$, then results cannot be relied upon in the hydrochemical interpretations. Also, water suitability for drinking can be determined by using the water quality index (WQI) which is very efficient because it is based on several variables that are formulated digitally, which involves the effect of these variables on the water quality (Salih, 2018) \& (Awadh, 2016), WQI can be found by using several equations as follows:

$$
\mathrm{Wi}=\frac{\mathrm{K}}{\mathrm{Si}}=\frac{1}{\mathrm{Si}} .
$$


Where: (Wi) is the unit weight; $(\mathrm{K})$ is the constant of proportionality and (Si) water quality standards.

$$
\mathrm{Qi}=(\mathrm{Vi} / \mathrm{Si}) * 100
$$

Where: (Qi) water quality rating, (Vi) averages of the data observed, $(\mathrm{Si})$ water quality standards.

$$
\mathrm{QpH}=[(\mathrm{VpH}-7.0) / 1.5] * 100
$$

Where: $\mathrm{QpH}$ is the quality rating for $\mathrm{Ph}, \mathrm{V}_{\mathrm{pH}}$ is the value of $\mathrm{pH}$ observed

$$
\mathrm{WQI}=\left[\sum(\mathrm{Qi} . \mathrm{Wi}) / \sum \mathrm{Wi}\right]
$$

The value of WQI reflects the suitability of water for drinking and the higher this value is the higher is the unsuitability of water for drinking, as shown in Table 2.

Table 2. Classification of water quality depending on WQI values (Armah et al., 2012)

\begin{tabular}{lc}
\hline WQI & Type of water \\
\hline$<50$ & Excellent \\
$50-100$ & Good \\
$100-200$ & Poor \\
$200-300$ & Very Poor \\
$>300$ & Unsuitable \\
\hline
\end{tabular}

For simplicity, assume $\mathrm{K}=1$, and for $\mathrm{pH}$, assuming the same unit weight as for chlorides (0.004), (Pius et al., 2012). The unit weight Wi from equation 3 with $\mathrm{K}=1$, is shown in Table. 3 with WHO, 2006 and Iraqi guidelines.

Table 3. The ranges of ions concentrations of the spring water in the study area and comparing them with the acceptable limits of the World Health Organization (WHO) and the standard Iraqi Specifications of drinking water

\begin{tabular}{lcccc}
\hline Parameter & Range & WHO guideline $(\mathbf{S i})$ & Iraqi guideline (2009) & Unit weight (Wi) \\
\hline $\mathrm{PH}$ & $6.7-7.45$ & $6.5-8.5$ & $6.5-8.5$ & 0.004 \\
$\mathrm{EC}(\mu \mathrm{S} / \mathrm{cm})$ & $432-765$ & $<1000-2000$ & 1500 & 0.001 \\
$\mathrm{TDS}(\mathrm{ppm})$ & $277-489.8$ & 1000 & 1000 & 0.001 \\
$\mathrm{TH}(\mathrm{ppm})$ & $187-388$ & 500 & 500 & 0.002 \\
$\mathrm{Ca}^{++}(\mathrm{ppm})$ & $51.1-100.8$ & 75 & 200 & 0.0133 \\
$\mathrm{Mg}^{++}(\mathrm{ppm})$ & $7.8-44.9$ & 100 & 150 & 0.01 \\
$\mathrm{Na}^{+}(\mathrm{ppm})$ & $0.4-11$ & 250 & 200 & 0.004 \\
$\mathrm{~K}^{+}(\mathrm{ppm})$ & $0.12-2.7$ & 12 & 3 & 0.0833 \\
$\mathrm{Cl}^{-}(\mathrm{ppm})$ & $5.8-18$ & 250 & 250 & 0.004 \\
$\mathrm{HCO}_{3}^{-}(\mathrm{ppm})$ & $202-342$ & 350 & 200 & 0.0029 \\
$\mathrm{SO}^{2-}(\mathrm{ppm})$ & $9.2-140.1$ & 250 & 250 & 0.004 \\
$\mathrm{NO}_{3}^{-}(\mathrm{ppm})$ & $2.4-20$ & 50 & 50 & 0.004 \\
\hline
\end{tabular}

Also validating of water for irrigation purposes has also been studied through several classifications, which are mentioned below: -

The classification that depends on the concentration of Sodium ion percentage, which can be calculated from the following equation:

$$
\mathrm{Na} \%=\frac{\mathrm{rNa}+\mathrm{rK}}{\mathrm{rCa}+\mathrm{rMg}+\mathrm{rNa}+\mathrm{rK}} * 100
$$

These percentages should be represented by epm If the percentage of $\mathrm{Na} \%$ was more than 80 then water is considered harmful to the plants and soil (Don, 1995) (Table 4). 
Table 4. Classification of irrigation water depending on the concentration of Sodium

\begin{tabular}{lc}
\hline $\mathbf{N a} \%$ & Water type \\
\hline 20 & Excellent \\
$20-40$ & Good \\
$40-60$ & Permissible \\
$60-80$ & Doubtful \\
$>80$ & Unsuitable \\
\hline
\end{tabular}

Moreover, springs water was evaluated for irrigation depending on the sodium adsorption ratio (SAR) as this index measures the ratio of $\mathrm{Na}^{+}$ions to the ratio of $\mathrm{Ca}^{+2}$ and $\mathrm{Mg}^{+2}$ ions.

Sodium has a negative effect on plants as it decreases the soil porosity due to the ionic exchange with calcium and magnesium, which eventually results in soil hardness.

SAR is determined according to the following equation (Todd, 2007):

$$
\mathrm{SRA}=\mathrm{rNa} /\{(\mathrm{rCa}+\mathrm{rMg}) / 2\}^{1 / 2}
$$

Ratios in the above equation must be represented by epm, the suggested specifications are as in the Table 5 according to the classification of Turgeon (2000).

Table 5. The ratios of SAR (Turgeon, 2000)

\begin{tabular}{lc}
\hline (SAR) Ratio & Water type \\
\hline 10 & Excellent \\
$10-18$ & Good \\
$18-26$ & Unsuitable \\
$>26$ & Poor \\
\hline
\end{tabular}

There is another classification related to Eaton (1950), which is the residual sodium carbonate (RSC) depends on the concentrations of bicarbonate relative to the concentrations of calcium and magnesium, which can be determined by the following equation:

$$
\mathrm{RSC}=(\mathrm{CO} 3+\mathrm{HCO})-(\mathrm{Ca}+\mathrm{Mg})
$$

Ratios in the equation above are expressed by the unit epm.

The high concentration of bicarbonate in water causes an increase in the precipitation of $\mathrm{Ca}^{2+}, \mathrm{Mg}^{2+}$ ions in the soil, and consequently, the quantity of sodium in the soil will increase due to the replacement of calcium and magnesium. Using water with a ratio of RSC higher than $2.5 \mathrm{meq} / \mathrm{l}$ leads to the accumulation of salts that obstruct the movement of air and water in the soil and eventually result in the deterioration of the soil Table.6 shows the classification of water depending on RSC.

A negative RSC indicates that sodium buildup is unlikely since sufficient calcium and magnesium are in excess of what can be precipitated as Carbonates. A positive RSC indicates that sodium buildup in the soil is possible (Turgeon, 2000).

Table 6. Water suitability for irrigation depending on RSC Eaton (1950)

\begin{tabular}{lc}
\hline (RSC) & Water type \\
\hline$<1.25$ & Excellent \\
$1.25-2.5$ & Intermediate \\
$>2.5$ & Bad \\
\hline
\end{tabular}




\section{Results and Discussion}

Ideally, drinking water should be colorless and odorless, the color in water is due to the existence of organic materials, minerals, bacteria, and dissolved gases, and this is a preliminary indicator of pollution risk, all samples in the area studies were colorless and odorless.

The average $\mathrm{pH}$ value was 7.18, except SP7 and SP10 were reduced to 6.9 - 6.7 respectively; this indicates that the water is neutral or slightly alkaline. On the other hand, the average value of EC of these spring waters was $522.5 \mu \mathrm{S} / \mathrm{cm}$ and this value is within the accepted specifications of water. the results of representing the springs water analysis by equations 1 and 2 and the results of the analysis of cations, anions, and hydrochemical parameters are given in Table 7.

Table.7. The concentrations of the cations, anions, accuracy, and hydrochemical parameters for the springs water of the study area

\begin{tabular}{|c|c|c|c|c|c|c|c|c|c|c|c|c|c|c|c|c|c|}
\hline \multirow[t]{2}{*}{ Spring } & \multirow[t]{2}{*}{ Unit } & \multicolumn{4}{|c|}{ Cations } & \multirow[t]{2}{*}{$\begin{array}{c}\text { Sum. } \\
\text { Cations }\end{array}$} & \multicolumn{4}{|c|}{ Anions } & \multirow{2}{*}{$\begin{array}{c}\text { Sum. } \\
\text { Anions }\end{array}$} & \multirow{2}{*}{$\begin{array}{l}\mathbf{E} \\
\%\end{array}$} & \multirow[t]{2}{*}{ A\% } & \multirow[t]{2}{*}{ pH } & \multirow[t]{2}{*}{ EC } & \multirow[t]{2}{*}{ TDS } & \multirow[t]{2}{*}{$\mathbf{T H}$} \\
\hline & & $\mathbf{C a}^{+2}$ & $\mathbf{M g}^{+2}$ & $\mathrm{Na}^{+}$ & $\mathbf{K}^{+}$ & & $\mathrm{Cl}^{-}$ & $\mathrm{SO}_{4}^{-2}$ & $\mathrm{NO}_{3}{ }^{-}$ & $\mathrm{HCO3}^{-}$ & & & & & & & \\
\hline \multirow{4}{*}{$\mathrm{Sp} 1$} & ppm & 73.70 & 36.20 & 2.50 & 0.70 & 113.10 & 13.00 & 42.10 & 9.80 & 298.00 & 362.90 & & & & & & \\
\hline & epm & 3.69 & 2.98 & 0.11 & 0.02 & 6.79 & 0.37 & 0.88 & 0.16 & 4.89 & 6.29 & 3.8 & 96.2 & 7.1 & 539.2 & 345 & 333 \\
\hline & epm\% & 54.26 & 43.87 & 1.60 & 0.26 & 100.00 & 5.90 & 13.94 & 2.51 & 77.64 & 100.0 & & & & & & \\
\hline & ppm & 83.00 & 23.00 & 2.10 & 0.32 & 108.42 & 14.00 & 48.00 & 13.00 & 256.00 & 331.00 & & & & & & \\
\hline \multirow[t]{3}{*}{ SP2 } & epm & 4.15 & 1.89 & 0.09 & 0.01 & 6.14 & 0.40 & 1.00 & 0.21 & 4.20 & 5.81 & 2.8 & 97.2 & 7.5 & 478.8 & 306.5 & 302 \\
\hline & epm\% & 67.56 & 30.82 & 1.49 & 0.13 & 100.00 & 6.89 & 17.22 & 3.61 & 72.28 & 100.00 & & & & & & \\
\hline & ppm & 99.20 & 7.80 & 2.40 & 0.90 & 110.30 & 12.00 & 49.30 & 7.40 & 236.00 & 304.70 & & & & & & \\
\hline \multirow[t]{3}{*}{ SP3 } & epm & 4.96 & 0.64 & 0.10 & 0.02 & 5.73 & 0.34 & 1.03 & 0.12 & 3.87 & 5.36 & 3.4 & 96.7 & 7.2 & 485 & 310.4 & 280 \\
\hline & epm\% & 86.57 & 11.20 & 1.82 & 0.40 & 100.00 & 6.40 & 19.17 & 2.23 & 72.21 & 100.00 & & & & & & \\
\hline & ppm & 88.00 & 10.70 & 4.10 & 1.80 & 104.60 & 14.00 & 58.60 & 13.50 & 202.00 & 288.10 & & & & & & \\
\hline \multirow[t]{3}{*}{ SP4 } & epm & 4.40 & 0.88 & 0.18 & 0.05 & 5.51 & 0.40 & 1.22 & 0.22 & 3.31 & 5.15 & 3.3 & 96.7 & 7.2 & 432.8 & 277 & 264 \\
\hline & epm\% & 79.93 & 16.00 & 3.24 & 0.84 & 100.00 & 7.77 & 23.71 & 4.23 & 64.30 & 100.00 & & & & & & \\
\hline & ppm & 96.00 & 19.50 & 0.40 & 2.70 & 118.60 & 14.00 & 43.10 & 3.00 & 300.00 & 360.10 & & & & & & \\
\hline \multirow[t]{3}{*}{ SP5 } & epm & 4.80 & 1.60 & 0.02 & 0.07 & 6.49 & 0.40 & 0.90 & 0.05 & 4.92 & 6.26 & 1.8 & 96.2 & 7.1 & 541.6 & 346.6 & 320 \\
\hline & epm\% & 73.94 & 24.72 & 0.27 & 1.07 & 100.00 & 6.39 & 14.33 & 0.77 & 78.51 & 100.00 & & & & & & \\
\hline & ppm & 84.80 & 39.00 & 3.10 & 0.50 & 127.40 & 12.00 & 55.30 & 3.60 & 314.00 & 384.90 & & & & & & \\
\hline \multirow[t]{3}{*}{ SP6 } & epm & 4.24 & 3.21 & 0.13 & 0.01 & 7.60 & 0.34 & 1.15 & 0.06 & 5.15 & 6.70 & 6.3 & 93.7 & 7.2 & 502.3 & 321.5 & 372 \\
\hline & epm\% & 55.81 & 42.25 & 1.77 & 0.17 & 100.00 & 5.12 & 17.19 & 0.87 & 76.82 & 100.00 & & & & & & \\
\hline & ppm & 80.00 & 40.00 & 2.90 & 0.70 & 123.6 & 12.00 & 51.30 & 4.90 & 308.00 & 376.20 & & & & & & \\
\hline SP7 & epm & 4.00 & 3.29 & 0.13 & 0.02 & 7.44 & 0.34 & 1.07 & 0.08 & 5.05 & 6.54 & 6.4 & 93.6 & 6.9 & 568.2 & 363.6 & 364 \\
\hline & epm\% & 53.79 & 44.27 & 1.70 & 0.24 & 100.00 & 5.24 & 16.34 & 1.21 & 77.21 & 100.00 & & & & & & \\
\hline & ppm & 78.40 & 20.50 & 2.60 & 0.50 & 102.00 & 10.00 & 27.90 & 8.50 & 244.00 & 290.40 & & & & & & \\
\hline SP8 & epm & 3.92 & 1.69 & 0.11 & 0.01 & 5.73 & 0.29 & 0.58 & 0.14 & 4.00 & 5.00 & 6.8 & 93.2 & 7.2 & 438.3 & 280.5 & 280 \\
\hline & epm\% & 68.37 & 29.43 & 1.97 & 0.22 & 100.00 & 5.71 & 11.62 & 2.74 & 79.94 & 100.00 & & & & & & \\
\hline & ppm & 72.00 & 44.90 & 11.0 & 1.10 & 129.00 & 18.00 & 140.1 & 3.20 & 276.00 & 437.30 & & & & & & \\
\hline SP9 & epm & 3.60 & 3.70 & 0.48 & 0.03 & 7.80 & 0.51 & 2.92 & 0.05 & 4.52 & 8.01 & 1.3 & 96.7 & 7.1 & 544 & 348.2 & 364 \\
\hline & epm $\%$ & 46.14 & 47.37 & 6.13 & 0.36 & 100.00 & 6.42 & 36.44 & 0.64 & 56.49 & 100.00 & & & & & & \\
\hline & ppm & 100.8 & 33.20 & 2.40 & 0.40 & 136.80 & 14.00 & 57.80 & 4.50 & 342.00 & 418.30 & & & & & & \\
\hline SP10 & epm & 5.04 & 2.73 & 0.10 & 0.01 & 7.89 & 0.40 & 1.20 & 0.07 & 5.61 & 7.28 & 4.0 & 96.0 & 6.7 & 542.2 & 347 & 388 \\
\hline & epm\% & 63.90 & 34.65 & 1.32 & 0.13 & 100.00 & 5.49 & 16.53 & 1.00 & 76.98 & 100.00 & & & & & & \\
\hline & $\mathrm{ppm}$ & 73.00 & 23.40 & 5.40 & 1.30 & 103.10 & 16.00 & 75.00 & 2.40 & 215.00 & 308.40 & & & & & & \\
\hline SP11 & epm & 3.65 & 1.93 & 0.23 & 0.03 & 5.84 & 0.46 & 1.56 & 0.04 & 3.52 & 5.58 & 2.3 & 97.7 & 7.3 & 765 & 489.8 & 278 \\
\hline & epm $\%$ & 62.46 & 32.96 & 4.02 & 0.57 & 100.00 & 8.19 & 27.99 & 0.69 & 63.13 & 100.00 & & & & & & \\
\hline & ppm & 62.00 & 35.10 & 1.45 & 0.20 & 98.75 & 12.00 & 33.20 & 10.20 & 273.00 & 328.4 & & & & & & \\
\hline SP12 & epm & 3.10 & 2.89 & 0.06 & 0.01 & 6.06 & 0.34 & 0.69 & 0.16 & 4.48 & 5.67 & 3.3 & 96.7 & 7.1 & 474 & 303.3 & 299 \\
\hline & epm $\%$ & 51.18 & 47.69 & 1.04 & 0.08 & 100.00 & 6.04 & 12.19 & 2.90 & 78.87 & 100.00 & & & & & & \\
\hline & ppm & 58.00 & 12.80 & 1.35 & 0.30 & 72.45 & 8.10 & 19.90 & 5.30 & 218.00 & 251.30 & & & & & & \\
\hline SP13 & epm & 2.90 & 1.05 & 0.06 & 0.01 & 4.02 & 0.22 & 0.41 & 0.09 & 3.57 & 4.31 & 3.4 & 96.6 & 7.3 & 437.4 & 279.9 & 197 \\
\hline & epm\% & 72.14 & 26.21 & 1.46 & 0.19 & 100.00 & 5.38 & 9.63 & 1.99 & 83.01 & 100.00 & & & & & & \\
\hline & ppm & 51.10 & 16.30 & 1.63 & 0.33 & 69.36 & 5.80 & 35.00 & 4.50 & 202.00 & 247.30 & & & & & & \\
\hline SP14 & epm & 2.56 & 1.34 & 0.07 & 0.01 & 3.98 & 0.17 & 0.73 & 0.07 & 3.31 & 4.28 & 3.7 & 96.3 & 7.3 & 570 & 364.8 & 195 \\
\hline & epm\% & 64.26 & 33.74 & 1.78 & 0.21 & 100.00 & 3.87 & 17.04 & 1.70 & 77.39 & 100.00 & & & & & & \\
\hline
\end{tabular}




\begin{tabular}{|c|c|c|c|c|c|c|c|c|c|c|c|c|c|c|c|c|c|}
\hline \multirow{3}{*}{ SP15 } & $\mathrm{ppm}$ & 57.00 & 10.80 & 2.70 & 0.12 & 70.62 & 6.00 & 9.20 & 20.00 & 211.00 & 246.20 & & & & & & \\
\hline & epm & 2.85 & 0.89 & 0.12 & 0.00 & 3.86 & 0.17 & 0.19 & 0.32 & 3.46 & 4.14 & 3.6 & 96.4 & $\begin{array}{c}7.4 \\
5\end{array}$ & 518 & 331.5 & 187 \\
\hline & epm $\%$ & 73.85 & 23.03 & 3.04 & 0.08 & 100.00 & 4.14 & 4.62 & 7.78 & 83.46 & 100.00 & & & & & & \\
\hline MIN & ppm & 51.1 & 7.8 & 0.4 & 0.12 & & 5.8 & 9.2 & 2.4 & 202 & & & & 6.7 & 432 & 277 & 187 \\
\hline MAX & ppm & 100.8 & 44.9 & 11 & 2.7 & & 18 & 140.1 & 20 & 342 & & & & 7.5 & 765 & 489.8 & 388 \\
\hline Mean & ppm & 77.13 & 24.88 & 3.07 & 0.79 & & 12.06 & 49.72 & 7.59 & 259.67 & & & & $\begin{array}{c}7.1 \\
8 \\
\end{array}$ & 522.45 & $\begin{array}{c}334.3 \\
7 \\
\end{array}$ & $\begin{array}{r}294 \\
87 \\
\end{array}$ \\
\hline
\end{tabular}

As for the TH, the average value was $294.8 \mathrm{mg} / \mathrm{l}$. the classification of Todd (1980) for hardness, it was clear that the water of the springs SP3, SP4, SP8, SP11, SP12, SP13, SP14, and SP15 falls within the limit of hard water, and SP1, SP2, SP5, SP6, SP7, SP9, and SP10 are within the limit of very hard water. the reason of this hardness is the limestone and the dolomitic limestone that form Aqra and Peris anticlines, but in general, it lies within the international specifications of drinking water that has a limit of $<500 \mathrm{mg} / \mathrm{l}$. There is a correlation between water hardness and total alkalinity that results from hydroxide and bicarbonate ions, and when water alkalinity is due to the existence of carbonates and bicarbonate, then the total alkalinity values become close to the hardness (Khalil, 2003). Fig..4 shows the strong correlation between hardness and total alkalinity which was $r^{2}=0.79$ for the water of springs in the study area (Table 8).

Table 8. Classification of water-based on the hardness

\begin{tabular}{lc}
\hline Hardness $(\mathbf{m g} / \mathbf{l})$ & Water quality \\
\hline $0-75$ & Fresh \\
$75-150$ & Medium \\
$150-300$ & Hard \\
$>300$ & Very hard \\
\hline
\end{tabular}

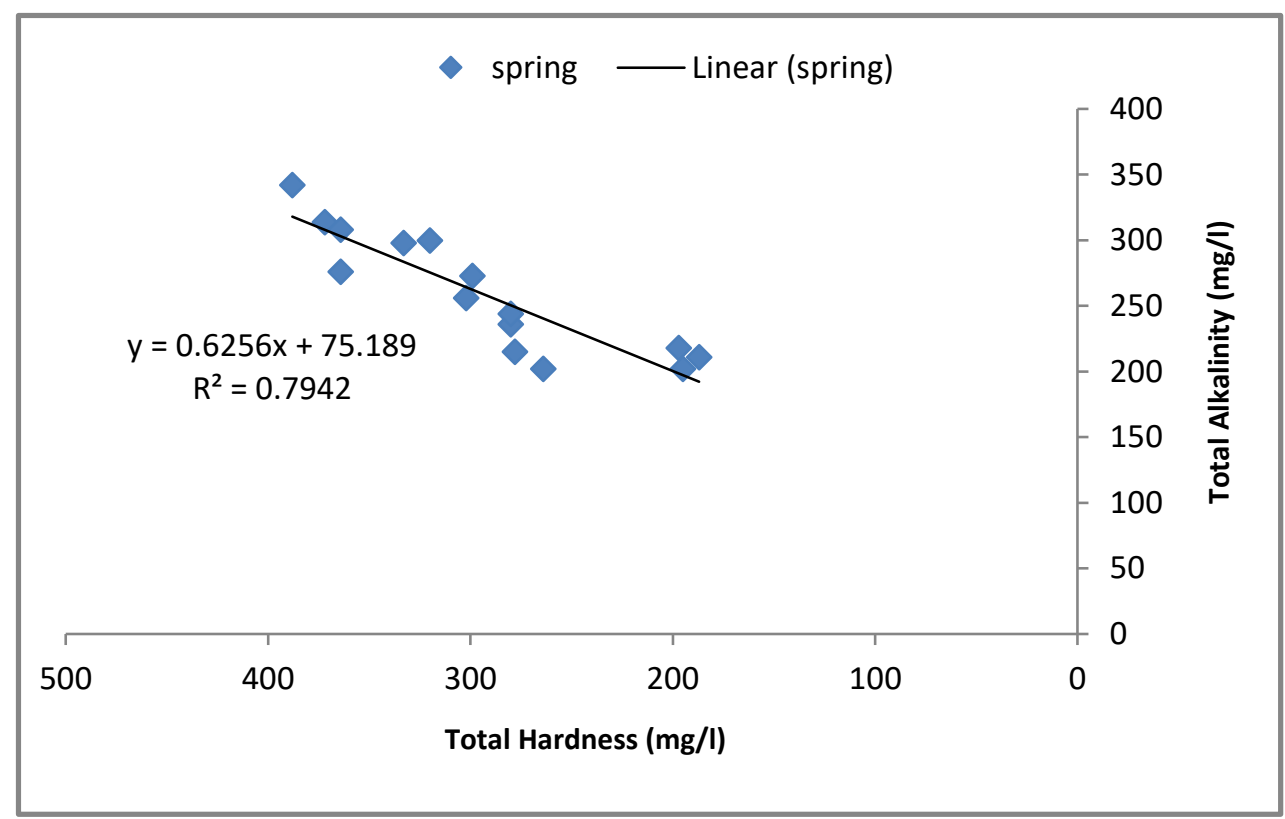

Fig. 4. The relationship between $\mathrm{TH}$ and $\mathrm{TAl}$

The TDS of the spring water in the study area (with an average $334.7 \mathrm{mg} / \mathrm{l}$ ) are within the freshwater category of the classification of Todd (2005), Table 9 This reflects its validity as drinking water (Fig. $5)$. 
Table 9. Classification of water based on the total dissolved solids

\begin{tabular}{lc}
\hline Water class & TDS mg/L \\
\hline Fresh water & $<1000$ \\
Slightly saline & $1000-3000$ \\
Moderately saline & $3000-10000$ \\
Very saline & $10000-35000$ \\
Brine & $>35000$ \\
\hline
\end{tabular}

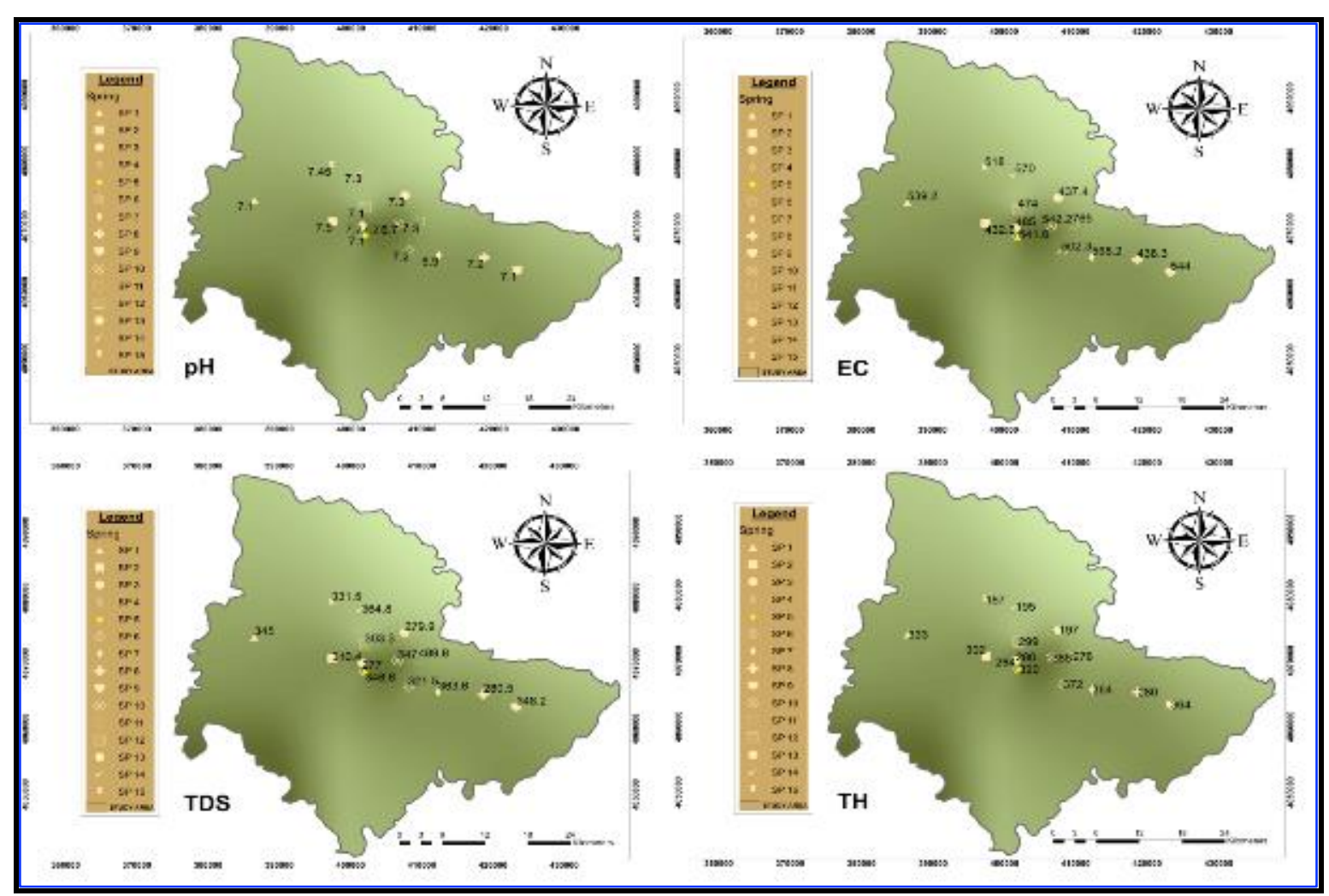

Fig. 5. Contour maps show the distribution of hydrochemical variables in the springs of the study area

For the cations, Table 7 shows a prevalence of calcium as its average value was $77.1 \mathrm{mg} / \mathrm{l}$, the highest calcium ions value was recorded at SP10 which was $100.8 \mathrm{mg} / \mathrm{l}$, this ratio falls within the Iraqi standard specifications for drinking water IQS, 2009 which allows calcium to reach $200 \mathrm{mg} / \mathrm{l}$, but it deviates slightly from the limits of WHO, 2006 which allows the calcium content to reach $75 \mathrm{mg} / \mathrm{l}$ this increase is caused by the spread of carbonate rocks in the study area. The average value of magnesium was $24.88 \mathrm{mg} / \mathrm{l}$, from Fig. 6, it is noticeable that the ion increases in the springs SP6, SP7, and SP9 to the east of the city of Aqra towards the Greater Zab River where the Bakhme Formation, which is made of dolomitic rocks. for sodium ions, the average value was $3.07 \mathrm{mg} / \mathrm{l}$; the highest value was recorded at the spring SP9, which originates near the Fatha Formation, which may be a source of this ion in the water, while the lowest percentage was at the spring SP5 on the Aqrah Formation as shown in Fig. 6. for potassium the average value was $0.79 \mathrm{mg} / \mathrm{l}$ which falls within the standard specifications for drinking water. The chemical analysis shows a prevalence of bicarbonate ions as its average was $259.7 \mathrm{mg} / \mathrm{l}$ due to the tremendous number of the limestone and dolomitic limestone rock in Aqra and Peris anticlines, the percentage of bicarbonate exceeds the Iraqi standard limits for drinking water IQS, 2009, which allows the presence of $<200 \mathrm{mg} / \mathrm{l}$ but it did not exceed the specifications of WHO, 2006, which allows 
the presence of $<350 \mathrm{mg} / \mathrm{l}$ (Fig. 7). The chloride ion concentration was $12.06 \mathrm{mg} / \mathrm{l}$ as an average; the highest value was recorded at the spring SP9 $18 \mathrm{mg} / \mathrm{l}$, which originates from the contact between Pila Spi - Fatha formation, which is the reason for adding this ion to the water. The sulfate ion concentration in the spring water in the area concerned was $49.72 \mathrm{mg} / \mathrm{l}$ as an average; and the highest concentration for this ion was in SP 9 as it was 140 ppm because of the closeness of this spring to Al-Fatha Formation that includes gypsum and evaporates (Fig. 7). Generally, these values are within the limits of drinking water specifications. The nitrate concentration with an average $7.6 \mathrm{mg} / \mathrm{l}$; the highest value of nitrate was recorded at the spring SP15, reason is due to the use of agricultural chemical fertilizers in the area near the spring.

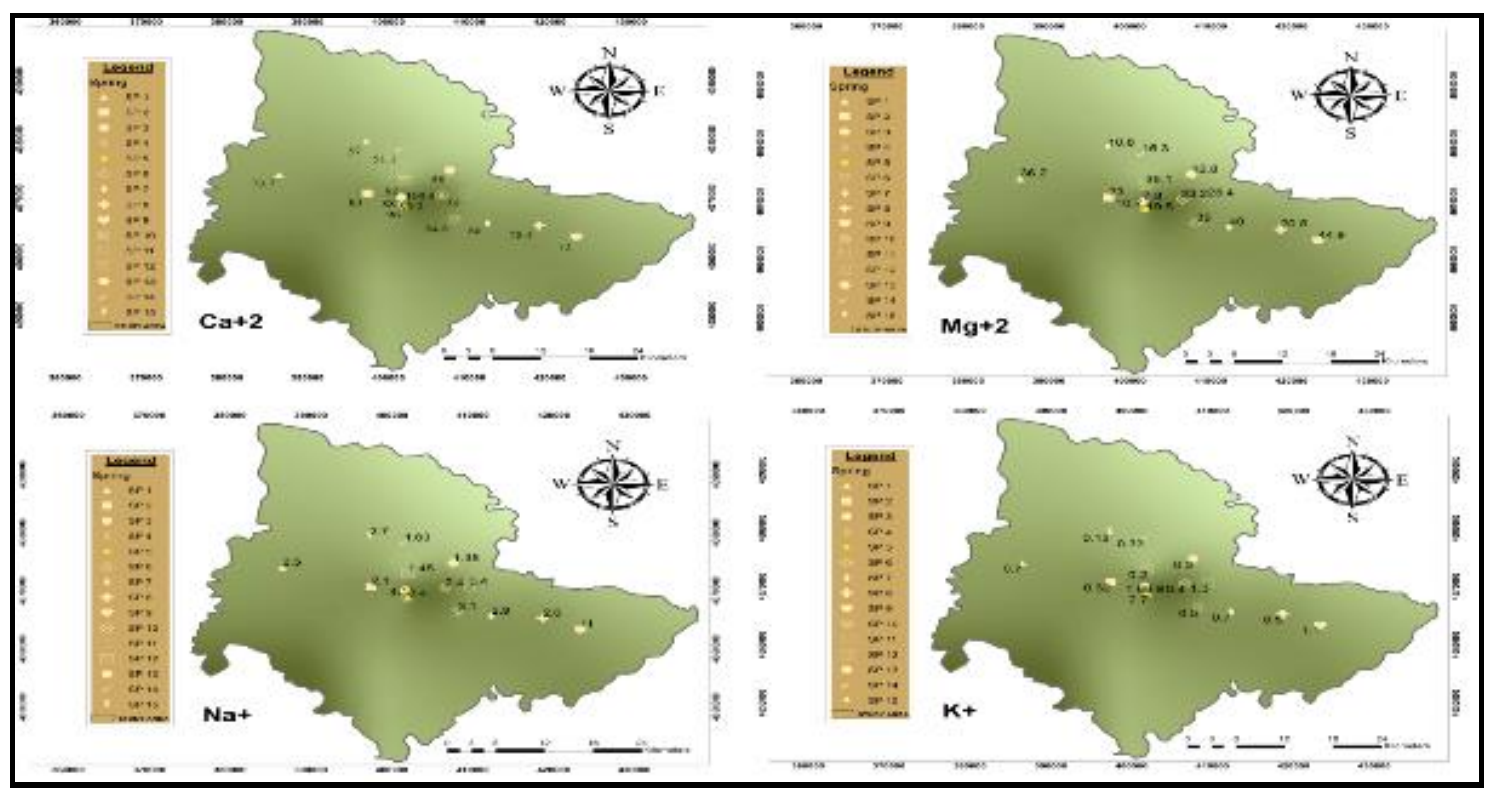

Fig. 6. Contour maps show the distribution of the cations in the study area

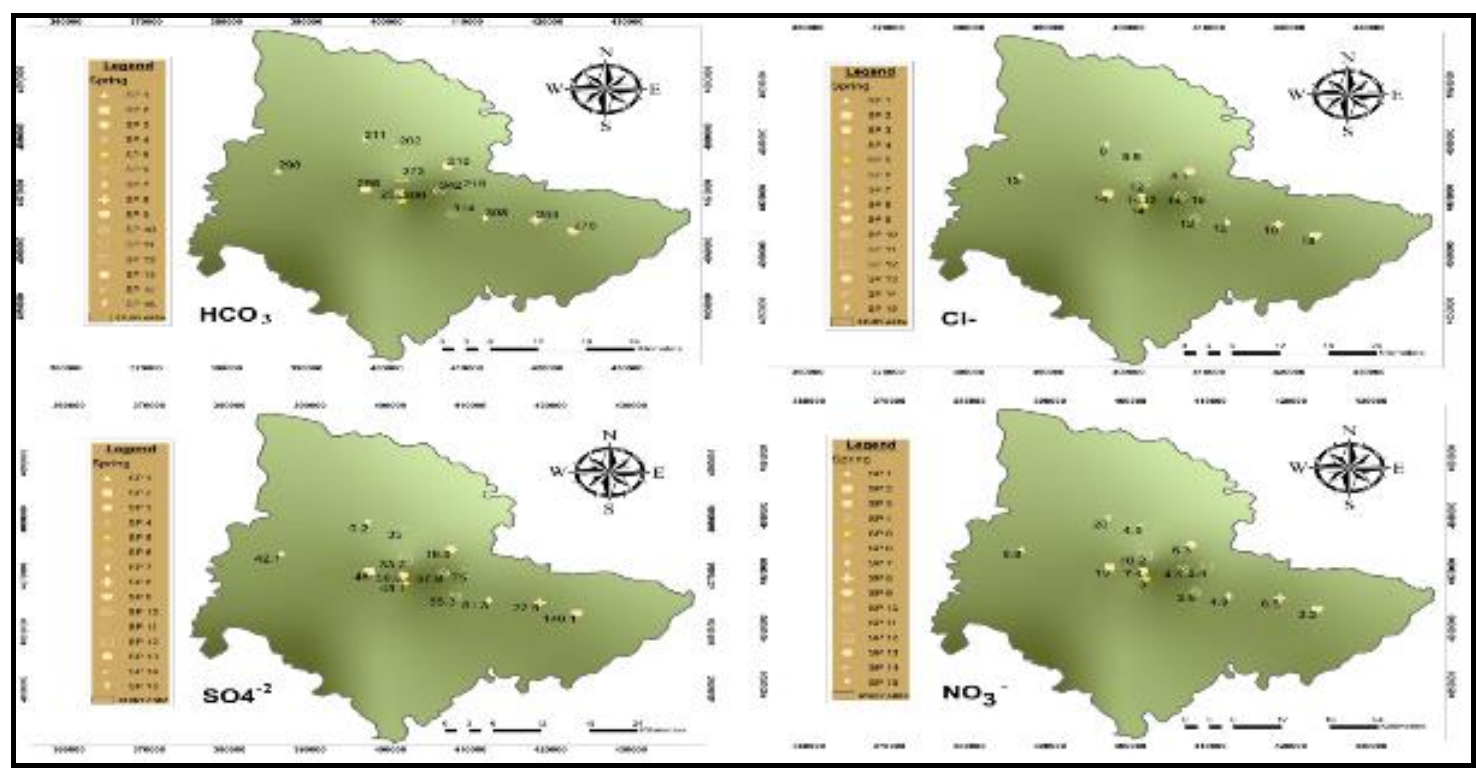

Fig. 7. Distribution of the anions in the study area

To identify the type of water in the study area, Aqua-Chem software was used, with using Piper classification (1944) within this program. The springs water in this area were identified, it was shown 
that calcium and magnesium are preponderance among the other cations $\mathrm{Ca}>\mathrm{Mg}>\mathrm{Na}>\mathrm{K}$, on the other hand bicarbonate is the preponderance anions $\mathrm{HCO}_{3}>\mathrm{SO}_{4}>\mathrm{Cl}>\mathrm{NO}_{3}$. It is also clear that the water contains calcium bicarbonate and that all samples lie within the field of normal earth alkaline water with prevailing bicarbonate and it is also observed that the sample SP9 lies within the field of normal earth alkaline water with prevailing bicarbonate and sulfate also the samples sp4 and sp11 are so close from the same field, as demonstrated in Fig. 8.

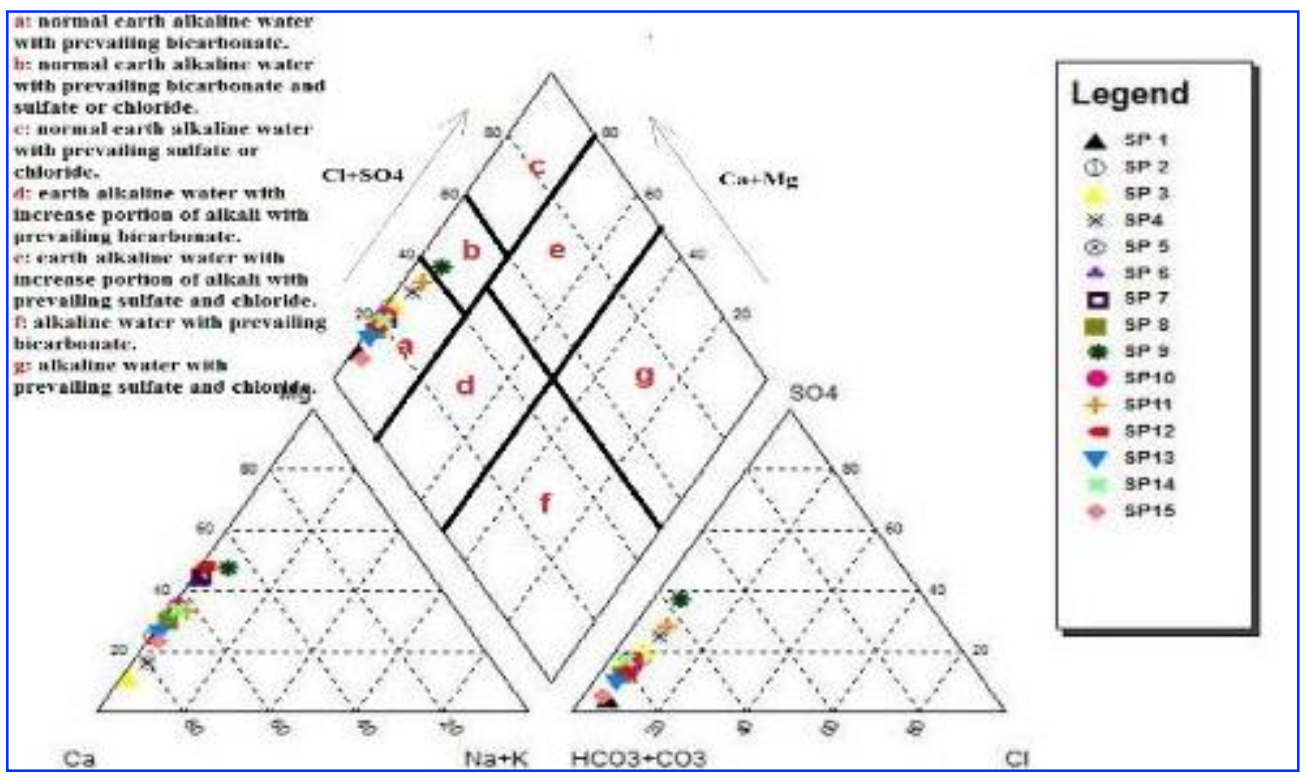

Fig. 8. Triple representation (Piper model) for the chemical analysis of the water samples in the study area

Four hydrochemical facies were identified, but the prevailing facies was calcium- magnesium bicarbonate, most of the springs fall within this type with a percentage of $80.0 \%$ of all samples, and the spring SP4 is of the type of calcium bicarbonate and sulfate with a percentage of $6.6 \%$, and the spring of SP9 is of the type bicarbonate and magnesium, calcium sulfate, which represents $6.6 \%$ and the spring SP11 of the type of bicarbonate and calcium, magnesium sulfate which represents $6.6 \%$ of all samples, Table.10 shows the springs and the water type and proportions in the study area. The variety in the springs water facies in the area denotes that they flow and stream through different rocky formations, and so they take calcium, magnesium, and bicarbonate from the rock of formations Aqra - Bakhme, Qamchuqa, and Pila Spi, and the sulfate is taken from the Fatha formation, because of many of these springs flow at the contact area between the formations and so this variety in water facies appears.

Table 10. The hydrochemical facies of the springs in the study area

\begin{tabular}{lcc}
\hline Well No. & Type of water & Percentage of studied water sample \\
\hline SP & Ca-Mg-HCO3 & $80.0 \%$ \\
$(1,2,3,5,6,7,8,10,12,13,14,15)$ & & $6.6 \%$ \\
SP 4 & Ca-HCO3-SO4 & $6.6 \%$ \\
SP 9 & Mg-Ca-HCO3-SO4 & $6.6 \%$ \\
SP 11 & Ca-Mg-HCO3-SO4 & \\
\hline
\end{tabular}




\subsection{Suitability of Water for Drinking}

After representing the results of the spring water analysis with the equations $(3,4,5,6)$, it was evident that this water is within the excellent field for human consumption as the water quality index showed a very low values, as shown in Table 11.

Table 11. The mathematical values and WQI values of the springs in the area of study

\begin{tabular}{|c|c|c|c|c|c|c|c|c|c|c|c|c|c|c|}
\hline SP & $\mathbf{P H}_{\mathrm{QiWi}}$ & $\mathbf{E C}_{\text {QiWi }}$ & TDS $_{\mathbf{Q i W i}}$ & $\mathbf{T H}_{\text {QiWi }}$ & $\mathrm{Ca}_{Q i W i}$ & $\mathbf{M g}_{Q_{\mathrm{QiW}}}$ & $\mathrm{Na}_{Q i W i}$ & $\mathbf{K}_{\mathbf{Q i W i}}$ & $\mathbf{C l}_{\mathbf{Q i W i}}$ & $\mathrm{SO}_{4 \mathrm{QiWi}}$ & $\mathrm{NO}_{3 \mathrm{QiWi}}$ & $\mathrm{HCO}_{3 \mathrm{QiWi}}$ & $\sum_{\text {QiWi }}$ & WQI \\
\hline SP1 & 0.0267 & 0.0539 & 0.0345 & 0.1332 & 1.3102 & 0.362 & 0.0040 & 0.4861 & 0.0208 & 0.0674 & 0.392 & 0.2433 & 3.1340 & 20.96 \\
\hline SP2 & 0.1333 & 0.0479 & 0.0307 & 0.1208 & 1.4755 & 0.230 & 0.0034 & 0.2222 & 0.0224 & 0.0768 & 0.520 & 0.2089 & 3.0920 & 20.68 \\
\hline SP3 & 0.0533 & 0.0485 & 0.0310 & 0.1120 & 1.7636 & 0.078 & 0.0038 & 0.6250 & 0.0192 & 0.0789 & 0.2960 & 0.1927 & 3.3020 & 22.08 \\
\hline SP4 & 0.0533 & 0.0433 & 0.0277 & 0.1056 & 1.5644 & 0.107 & 0.0066 & 1.2500 & 0.0224 & 0.0938 & 0.5400 & 0.1649 & 3.9790 & 26.61 \\
\hline SP5 & 0.0267 & 0.0542 & 0.0347 & 0.1280 & 1.7066 & 0.195 & 0.0006 & 1.8750 & 0.0224 & 0.0699 & 0.1200 & 0.2449 & 4.4771 & 29.94 \\
\hline SP6 & 0.0533 & 0.0502 & 0.0322 & 0.1488 & 1.5075 & 0.390 & 0.0050 & 0.3472 & 0.0192 & 0.0885 & 0.1440 & 0.2563 & 3.0423 & 20.35 \\
\hline SP7 & 0.0267 & 0.0568 & 0.0364 & 0.1456 & 1.4222 & 0.400 & 0.0046 & 0.4861 & 0.0192 & 0.0821 & 0.1960 & 0.2514 & 3.0738 & 20.56 \\
\hline SP8 & 0.0533 & 0.0438 & 0.0281 & 0.1120 & 1.3937 & 0.205 & 0.0042 & 0.3472 & 0.0160 & 0.0446 & 0.340 & 0.1992 & 2.7872 & 18.64 \\
\hline SP9 & 0.0267 & 0.0544 & 0.0348 & 0.1456 & 1.2800 & 0.449 & 0.0176 & 0.7638 & 0.0288 & 0.2242 & 0.1280 & 0.2253 & 3.3782 & 22.59 \\
\hline SP10 & 0.0800 & 0.0542 & 0.0347 & 0.1552 & 1.7920 & 0.332 & 0.0038 & 0.2777 & 0.0224 & 0.0925 & 0.180 & 0.2792 & 3.1438 & 21.03 \\
\hline SP11 & 0.0800 & 0.0765 & 0.0490 & 0.1112 & 1.2978 & 0.234 & 0.0086 & 0.9027 & 0.0256 & 0.1200 & 0.0960 & 0.1755 & 3.1770 & 21.25 \\
\hline SP12 & 0.0267 & 0.0474 & 0.0303 & 0.1196 & 1.1022 & 0.351 & 0.0023 & 0.1388 & 0.0192 & 0.0531 & 0.4080 & 0.2229 & 2.5216 & 16.86 \\
\hline SP13 & 0.0800 & 0.0437 & 0.0280 & 0.0788 & 1.0311 & 0.128 & 0.0022 & 0.2083 & 0.0130 & 0.0318 & 0.2120 & 0.1779 & 2.0349 & 13.61 \\
\hline SP14 & 0.0800 & 0.057 & 0.0365 & 0.0780 & 0.9084 & 0.163 & 0.0026 & 0.2291 & 0.0093 & 0.0560 & 0.1800 & 0.1649 & 1.9649 & 13.14 \\
\hline SP15 & 0.1200 & 0.0518 & 0.0332 & 0.0748 & 1.0133 & 0.108 & 0.0043 & 0.0833 & 0.0096 & 0.0147 & 0.8000 & 0.1722 & 2.4853 & 16.62 \\
\hline
\end{tabular}

\subsection{Suitability of Springs Water for Irrigation}

Many classifications were adopted that rely on various variables in the water used. The classification of Train, (1979) was used, as mentioned in Hussein and Al-Salem (2017) (Table 12), which depends on the total dissolved salts. After comparing the springs water in the area in question with these specifications, it was clear that this water causes no harmful effects to the plant as salts concentrations are less than $500 \mathrm{mg} / \mathrm{l}$.

Table 12. the classification of irrigation water depending on the TDS concentration, Train (1979)

\begin{tabular}{lc}
\hline \multicolumn{1}{c}{ Specifications } & TDS (ppm) \\
\hline Using this water for irrigation causes no harmful effects. & $<500$ \\
Using this water could cause harmful effects to the plants which are very & $500-1000$ \\
sensitive to salinity. & $1000-2000$ \\
Using this water might cause harmful effects to many crops so use of this \\
$\begin{array}{l}\text { water needs a good expertise. } \\
\text { This water can be used to irrigate plants that endure high salinity and its } \\
\text { use needs a good expertise. }\end{array}$ \\
\hline
\end{tabular}


Also; after representing results mentioned in Table 7 by the equations 7,8 and 9 and comparing the results with the classifications mentioned in Tables 4,5 and 6 it was clear that these waters are good for irrigation and it has no negative effect on the plants or the soil, as shown in Table 13.

Table 13. The ratios of the three parameters Na\%, SAR and RSC in the water of the study area

\begin{tabular}{cccc}
\hline Spring & Na\% & SAR & RSC \\
\hline SP 1 & 1.86 & 0.06 & -1.78 \\
SP 2 & 1.62 & 0.05 & -1.85 \\
SP 3 & 2.22 & 0.06 & -1.73 \\
SP 4 & 4.08 & 0.11 & -1.97 \\
SP 5 & 1.33 & 0.01 & -1.49 \\
SP 6 & 1.94 & 0.07 & -2.30 \\
SP 7 & 1.94 & 0.07 & -2.24 \\
SP 8 & 2.20 & 0.07 & -1.61 \\
SP 9 & 6.49 & 0.25 & -2.77 \\
SP 10 & 1.45 & 0.05 & -2.17 \\
SP 11 & 4.59 & 0.14 & -2.05 \\
SP 12 & 1.13 & 0.04 & -1.51 \\
SP 13 & 1.65 & 0.04 & -0.38 \\
SP 14 & 2.00 & 0.05 & -0.59 \\
SP 15 & 3.12 & 0.09 & -0.28 \\
\hline Mean & $\mathbf{2 . 5 1}$ & $\mathbf{0 . 0 8}$ & $\mathbf{- 1 . 6 5}$ \\
\hline
\end{tabular}

The samples were plotted on Wilcox Diagram (1955), which relies on the sodium percentage and the electrical conductivity; diagram is divided into five fields, it was evident that all samples lie within the domain of excellent irrigation water, as shown in Fig. 9.

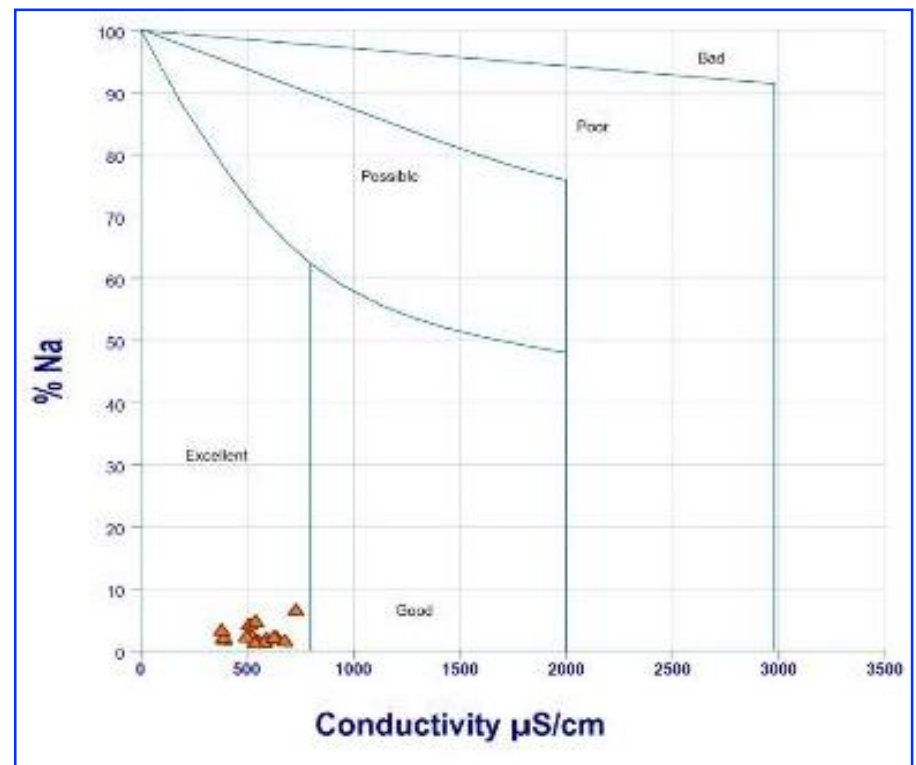

Fig. 9. A representation of the springs on (Wilcox, 1955) 


\section{Conclusions}

The springs in the studied area emerge due to the slow movement of the water through the tiny slits, pores, and rock cracks, and they flow out from the surface and it has no relatedness with the groundwater, the chemical analysis showed that these springs water are involved within the domain of hard-very hard water, and this hardness is temporary as it is caused by the ions of bicarbonate, calcium, and magnesium, and the springs of the study area are weakly acidic - slightly alkaline. Results showed that the type of the water is of calcium bicarbonate type and from observing the classification of Piper used; the bicarbonate ions were prevalent for the anions, while calcium and magnesium are the prevalent cations. Therefore, four hydrochemical facies were chemically identified, but the prevalent facies were calcium bicarbonate. Also, the water in the study area is good for human consumption as shown from the low values of WQI as this water is included within the excellent water for human consumption. The validity of the groundwater for irrigation was studied using a group of classifications $\mathrm{Na} \%$, SAR, RSC in addition to representing the results on Wilcox Diagram and it was clear that this water is of excellent quality for the purpose of irrigation.

\section{Acknowledgements}

The authors are very grateful to the Editor in Chief Prof. Dr. Salih M. Awadh, the Secretary of Journal Mr. Samir R. Hijab. and the Technical Editors for their great efforts and valuable comments.

\section{References}

Ahmed, N. A. I. Y., \& Almohseen, K. A. 2019. Evaluation and modeling of ground water for Aqra Aquifer. Iraqi National Journal of Earth Science, 19(2).

Al-Hamdani, J.A.J., Awadh, S.M. and Ibrahim, O.S., 2016. Geochemical partitioning of heavy metals in the urban soil, Kirkuk, Iraq. The Iraqi Geological Journal, 39-49 (1), 1-24.

Aqrawi, Z., A., 1990. Hydrogeology of Aqrah plain, M.Sc. thesis, University of Mosul, Mosul, Iraq, 120P.

Armah, F.A., Luginaah, I., \& Ason, B. 2012.Water quality index in the tarkwa gold mining area in Ghana, The Journal of Transdisciplinary Environmental Studies, 11(2), 14.

Awadh, S.M. and Ahmed, R.M., 2013. Hydrochemistry and pollution probability of selected sites along the Euphrates River, Western Iraq. Arabian Journal of geosciences, 6(7), 2501-2518.

Awadh, S.M. and Al-Ghani, S.A., 2014. Assessment of sulfurous springs in the west of Iraq for balneotherapy, drinking, irrigation and aquaculture purposes. Environmental geochemistry and health, 36(3), 359-373.

Awadh, S.M., 2018. A preliminary assessment of the geochemical factors affecting groundwater and surface water quality around the rural communities in Al-Anbar, Western Desert of Iraq. Environmental earth sciences, 77(3), 1-18.

Awadh, S.M., Al-Kilabi, J.A., \& Abdulhussein, F.M., 2016. Assessment of groundwater quality using water quality index in, Al-Hawija area, northern Iraq, Iraqi Geological Journal, 67-76.

Awadh, S.M., Al-Mimar, H. and Yaseen, Z.M., 2021. Groundwater availability and water demand sustainability over the upper mega aquifers of Arabian Peninsula and west region of Iraq. Environment, Development and Sustainability, 23(1), 1-21.

Baird, R.B., 2017. Standard Methods for the Examination of Water and Wastewater, 23rd. Water Environment Federation, American Public Health Association, American Water Works Association, 1545 pp.

Boschetti, T., Awadh, S.M. and Salvioli-Mariani, E., 2018. The Origin and $\mathrm{MgCl} 2-\mathrm{NaCl}$ Variations in an Athalassic Sag Pond: Insights from Chemical and Isotopic Data. Aquatic Geochemistry, 24(2), 137-162.

Dikeogu, T.C., Okeke, O.C., Ogbekhiulu, L.O., \& Ogbenna, P. C., 2018. Major ion chemistry and hydrochemical processes of Ngeneagu spring water at Akpugoeze Oji River, Enugu, and southeastern Nigeria, International Journal of Advanced Academic Research Sciences, Technology \& Engineering, 4(2), $13 \mathrm{pp}$.

Don, C. M., 1995. A grows guide to water quality. University college station, Texas, 601-609.

Eaton, F. M., 1950.Significance of carbonates in irrigation waters. Soil science, 69(2), 123-134. 
Ghafur, A. A., Sissakian, V. K., Abdulhaq, H. A., \& Omar, H. O. 2019. Aqra Anticline: A growing structure in the Iraqi Kurdistan Region. ARO-The Scientific Journal of Koya University, 7(2), 27-33.

Hadgu, L. T., Nyadawa, M. O., Mwangi, J. K., Kibetu, P. M., \& Mehari, B.B. (2014). Application of water quality model qual2k to model the dispersion of pollutants in river ndarugu, Kenya. Computational water, energy, and environmental engineering, 3(04), 162.

Hamill, L., Bell, F. G., 1986.Ground water resource development, Butterwerths; London, 344 pp.

Hem, J. D., 1985.Study and interpretation of the chemical characteristics of natural water (Vol. 2254). Department of the Interior, US Geological Survey.

Hussein, R. A. \& Al-Salem, T. H. A., 2017.Hydrochemistry and water quality for Alqosh-Kand Catchment Area North of Mosul, North of Iraq, Kirkuk University. Journal for Scientific Studies, 12(1), 94.

Iraqi Standards., 2009.Iraq standards of drinking water No.417, Second Modification.

Jassim, S. Z., \& Goff, J. C., 2006. Geology of Iraq: Dolin. Prague and Moravian Museum, Brno, Czech Republic, 5 .

Khalil, M. A., 2003. Preparing water for drinking and domestic use, Academic Library, Cairo, Egypt, 434 pp.

Medler, C. J. \& Eldridge, W. G., 2021. Spring types and contributing aquifers from water-chemistry and multivariate statistical analyses for seeps and springs in Theodore Roosevelt National Park, North Dakota, 2018 (No. 2020-5121). US Geological Survey.

Meuli, C., \& Wehrle, K., 2001. Spring Catchment-Series of Manuals on Drinking Water Supply. Swiss Center for Development Cooperation in Technology and Management-SKAT, Suiza. Piper, A. M., 1944. A graphic procedure in the geochemical interpretation of water-analyses. Eos, Transactions American Geophysical Union, 25(6), 914-928.

Piper, A.M., 1944. A graphic procedure in the geochemical interpretation of water analyses, Transition, American Geophysical union, 25, $914-923$.

Pius, A., Jerome, C., \& Sharma, N., 2012. Evaluation of groundwater quality in and around Peenya industrial area of Bangalore, South India using GIS techniques. Environmental monitoring and assessment, 184(7), 40674077.

Salih, Z. A., 2018. Evaluation of the efficiency of some water supply stations in Najaf Governorate using the weighted arithmetic index method (WQI). Muthanna Journal of Engineering and Technology (MJET), 6(2), 185-199.

Todd, D. K., 2005. Ground water Hydrology (3 edition). New York, USA, 650 pp.

Todd, D.K., 1980. Ground water hydrology, 2nd edition, Inc, New York. 278pp.

Todd, D.K., 2007. Groundwater Hydrology (2nd edit.). John Wiley and Sons, Third Reprint. India, 535pp.

Train, R.E., 1979. Quality Criteria for Water. Castle House Publication Ltd., London, UK.

Turgeon, A.J., 2000. Irrigation Water Quality, College of Agricultural sciences, The Pennsylvania State University, USA.

U.S. Geological Survey, 2019, Dictionary of Water Terms: U.S. Geological Survey.

Water, S., \& World Health Organization, 2006. Guidelines for Drinking Water Quality [electronic resource]: Incorporating First Addendum, Recommendations., 1.

Wilcox, L.V., 1955. Classification and use of irrigation waters. United States Department of Agriculture (USDA), Washington DC, USA, 939, 19. 